Отримано: 12 травня 2018 р.

Прорецензовано: 21 травня 2018 р.

Прийнято до друку: 29 травня 2018 р.

e-mail: ovbreol@ukr.net
Брежнєва-Срмоленко О. В. Перспективи поглиблення фіскальних децентралізаційних процесів в Україні. Наукові записки Наиіонального університету «Острозька академія». Серія «Економіка» : науковий журнал. Острог : Вид-во НаУОА, червень 2018. № 9(37). С. 111-116.

DOI: $10.25264 / 2311-5149-2018-9(37)-111-116$

УДК: 336.22:336.027

Брежнсва-Срмоленко Ольга Василівна,

кандидат економічних наук, доиент, доцент кафедри фінансів та обліку

Дніпровського державного технічного університету

ORCID: orcid.org/0000-0003-4518-6235.

\title{
ПЕРСПЕКТИВИ ПОГЛИБЛЕННЯ ФІСКАЛЬНИХ ДЕЦЕНТРАЛІЗАЦІЙНИХ ПРОЦЕСІВ В УКРАЇНІ
}

У статті проведено дослідження теоретичних і практичних аспектів реалізації децентралізаційних процесів у бюджетно-податковій сфері; розглянуто фіскальну децентралізацію як комплексну категорію; проаналізовано результативність впливу податкової реформи на сумарні показники виконання місцевих бюджетів за доходами; з'ясовано, що частка фінансових ресурсів, які отримують місиеві бюджети з державного бюджету досягає $50 \%$, що свідчить про вагомий фінансовий ресурс у розпорядженні місцевих органів влади; визначено, що посилення бюджетно-податкової децентралізації в Україні позитивно вплинуло на функціонування й умови розвитку місиевих бюджетів різних рівнів; запропоновано основні підходи та заходи для успішного поглиблення ефективної реалізації фіскальної децентралізації.

Ключові слова: податкова децентралізаиія; фіскальна деиентралізаиія; місиеві бюджети; міжбюджетні відносини; ефективність виконання функцій бюджету.

Брежнева-Ермоленко Ольга Васильевна, кандидат экономических наук, доцент, дочент кафедры финансов и учета Днепровского государственного технического университет

\section{ПЕРСПЕКТИВЫ УГЛУБЛЕНИЯ ФИСКАЛЬНЫХ ДЕЦЕНТРАЛИЗАЦИОННЫХ ПРОЦЕССОВ В УКРАИНЕ}

В статье проведено исследование теоретических и практических аспектов реализации децентрализационных процессов в бюджетно-налоговой сфере; рассмотрено фискальную децентрализацию как комплексную категорию; проанализированы результативность влияния налоговой реформы на суммарные показатели выполнения местных бюджетов по доходам; выяснено, что доля финансовых ресурсов, которые получают местные бюджеты из государственного бюджета достигает 50\%, что свидетельствует о весомом финансовом ресурсе в распоряжении местных органов власти; определено, что усиление бюджетно-налоговой децентрализации в Украине положительно повлияло на функционирование и условия развития местных бюджетов различных уровней; предложены основные подходы и методы для успешного углубления эффективной реализации фискальной децентрализации.

Ключевые слова: налоговая децентрализачия; фискальная децентрализация; местные бюджеты; межбюджетные отношения; эффективность выполнения функиий бюджета.

\author{
Olha Brezhnyeva-Yermolenko, \\ Ph. D. in Economics, Associate Professor, \\ Associate professor at the department of Finances and Accounting, Dniprovsky State Technical University
}

\section{THE PROSPECTS OF FISCAL DECENTRALIZATION DEEPENING IN UKRAINE}

The study of theoretical and practical aspects of the decentralization processes implementation in the fiscal-tax sphere was fulfilled. Fiscal decentralization is considered the as a comprehensive category. The tax reform impact on the summarized indicators of local budgets incomes implementation was analyzed. It was found that the share of financial resources, received by the local budgets from the state budget reaches $50 \%$, consequently it substantiates a presence of a significant financial resource at the disposal of local authorities. The authors determined that increase in fiscal decentralization in Ukraine positively reverberated on the functioning and conditions of local budgets development on different levels. The main approaches and measures for successful deepening of the fiscal decentralization implementation were suggested.

Key words: tax decentralization; fiscal decentralization; local budgets; inter-budgetary relations; performance of budget functions. 
Постановка проблеми. Проблема оптимального розподілу повноважень і фінансових ресурсів між центральними та місцевими органами влади $є$ однією з найбільш актуальних у контексті підвищення ефективності бюджетної системи України, адже від адекватного забезпечення перерозподілу фінансових ресурсів і від гнучкості способів їх використання значною мірою залежить стабільність економічного розвитку країни. На сьогодні питання проведення ефективної реформи, спрямованої на децентралізацію фінансових ресурсів і нормалізацію міжбюджетних відносин, є одним із пріоритетних напрямів реалізації урядової стратегії сталого розвитку «Україна - 2020».

За даними зазначеної стратегії, реформа бюджетної децентралізації містить у собі 2 основних етапи: I етап (2014-2016 рр.) охоплює розробку загальної концепції проведення реформи та безпосередню реалізацію ії основних аспектів, а ІІ етап (2017-2020рp.) - подальше вдосконалення міжбюджетних відносин, підвищення ефективності управління фінансовими ресурсами. Завершення I етапу проведення децентралізаційної реформи дозволяє проаналізувати ефективність основних трансформацій, які відбулись у бюджетній системі України, та визначити перспективи подальшої реалізації запланованої урядової програми. Зазначені питання викликають об'єктивну необхідність дослідження теоретичних і практичних аспектів реалізації децентралізаційних процесів у податковій сфері та розробку системи заходів, спрямованих на підвищення ефективності впровадження зазначеної реформи в Україні.

Аналіз останніх досліджень і публікацій. Тема викликає інтерес як у наукових колах, так і серед економістів, політиків і широких верств населення. Вагомий внесок у дослідження зазначеної проблеми зробили В. Валігура та Л. Амбрик, які досліджували фінансові аспекти фіскальної децентралізації в Україні. I. Кресіна проводила дослідження щодо впливу децентралізації на ефективність публічної влади. Також необхідно звернути увагу на роботи О. Бориславської, яка вивчала досвід європейських країн і проводила аналіз імовірних переваг щодо реалізації реформи фінансово-бюджетної децентралізації в Україні.

Виділення не вирішених раніше частин загальної проблеми. Водночас залишається ряд невизначених питань, до яких варто віднести впровадження заходів, спрямованих на підвищення ефективності наповнення дохідної частини місцевих бюджетів, реалізацію інтегративних підходів у сфері планування державного та місцевих бюджетів, використання міжнародного досвіду при проведенні фіскальної децентралізації. Актуальність питань обумовили напрям і необхідність подальших наукових пошуків.

Метою дослідження є дослідження результатів проведення I етапу податкової децентралізації в Україні та надання рекомендацій щодо підвищення ефективності фіскальних децентралізаційних процесів.

Виклад основного матеріалу. Відзначимо, що в теоретичних і практичних дослідженнях поняття «децентралізація» $є$ багатоаспектним і його розглядають різнопланово. На семантичному рівні децентралізація (від лат. de - «протиставлення», centralis - «центральний») пояснюють як знищення, ослаблення або скасування централізації [1, с. 249]. Водночас найбільш узагальненим визначенням терміна «децентралізація» в радянський період було розширення прав місцевих державних органів управління в результаті передання їм деяких функцій центральних органів [2, с. 137].

Податкову децентралізацію тлумачать як процес передачі надходжень від відповідних податків у володіння органів нижніх рівнів влади, що сприяє посиленню їх самостійності. Податки, закріплені на постійній або довгостроковій основі, забезпечують територіальним органам влади стійку фінансову базу для проведення самостійної бюджетно-податкової політики. Важливим складником податкової децентралізації є право цих органів на певний ступінь незалежності у встановленні податків на відповідному рівні, що передбачає як їх відповідальність у зв'язку із прийняттям зобов'язань із надання локальних громадських послуг, так і підзвітність перед населенням.

Головна мета фіскальної децентралізації полягає в досягненні фінансової незалежності органів місцевого самоврядування шляхом надання територіям необхідного фінансово-матеріального ресурсу з метою забезпечення ефективності й максимальної доступності публічних послуг для населення, вдосконалення системи управління, підвищення мобільності й ефективності вирішення місцевою владою поставлених завдань [3, с. 126-127].

Необхідно звернути увагу на структуру фіскальної децентралізації як комплексної категорії (рис. 1). За даними рисунка можна зробити висновок, що структура фіскальної децентралізації є органічним поєднанням таких складових елементів, як децентралізація доходів, видатків, процесуальну й організаційну самостійність. Поєднання даних структурних компонентів дозволяє охопити всі економічні сфери, на які децентралізаційні процеси здійснюють вплив, і досягати максимальної ефективності від їх реалізації.

Звідси можна стверджувати, що фіскальна децентралізація є невід'ємною складовою фінансової децентралізації, яка $є$ основою для проведення комплексної децентралізації в країні. Для повноцінної реалізації децентралізаційних процесів необхідно дотримуватись основних принципів децентралізації, затверджених Свропейською хартією місцевого самоврядування та розроблених науковцями. Питання посилення децентралізаційних процесів у бюджетній сфері України було прописано в ряді законів і Бюджетному кодексі, але активна діяльність у цьому напрямі почалась тільки з другої половини 2014 року. 


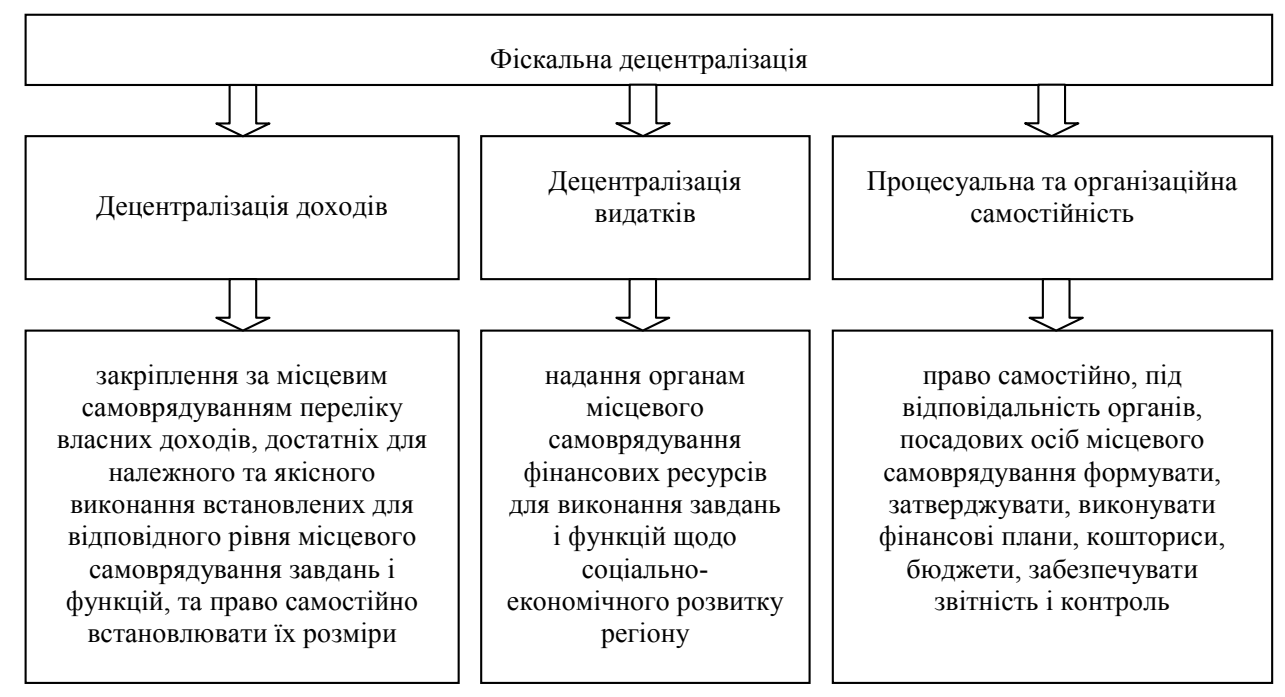

Рис. 1. Структура фіскальної децентралізації

Примітка. Складено автором за даними [4, с. 78$]$.

Фіскальна децентралізація тісно пов'язана з процесом реформування міжбюджетних відносин і здійснює на нього прямий вплив.

В Україні ситуація з розподілом податкових надходжень між ланками бюджетної системи України свідчить, що навіть після проведення I етапу бюджетної децентралізації основні бюджетоутворюючі податки залишаються в розпорядженні центральних органів влади (податок на прибуток підприємств 90\%, ПДВ - 100\%, рентні платежі - 50-75\%) [5]. До цього часу зберігається тенденція до концентрації бюджетних надходжень в державному бюджеті.

Особливої уваги у напрямі дослідження впливу децентралізації на організацію міжбюджетних відносин заслуговує питання розробки та реалізації механізму функціонування міжбюджетних трансфертів, які будуть відповідати умовам нової системи фінансових відносин, що будуть виникати між бюджетами різних рівнів. До основних змін, які відбулись у механізмі застосування трансфертного інструментарію в Україні, слід віднести заміну системи балансування бюджетів системою міжбюджетного вирівнювання, яка передбачає горизонтальне вирівнювання податкоспроможності територій залежно від рівня надходжень на одного жителя лише по податку на прибуток підприємств для обласних бюджетів та податку на доходи фізичних осіб - для бюджетів міст, районів та обласних бюджетів [6, с. 158].

Не менш важливим $€$ запровадження індексу податкоспроможності, який розраховують як відношення обсягу надходжень відповідного податку на 1 жителя до середнього значення по Україні [6, с. 159]. Також у новій системі міжбюджетного вирівнювання було введено нові види міжбюджетних трансфертів, які містять базову та реверсну дотації. Під базовою дотацією розуміють трансферт, що надається 3 державного бюджету місцевим бюджетам для горизонтального вирівнювання податкоспроможності територій. Реверсна дотація - це кошти, що передаються до державного бюджету з місцевих бюджетів для горизонтального вирівнювання податкоспроможності територій.

Позитивним моментом нової системи міжбюджетного вирівнювання $є$ те, що залишки коштів субвенцій на кінець бюджетного періоду зберігаються на рахунках відповідних місцевих бюджетів і їх використовують у наступному бюджетному періоді з урахуванням цільового призначення [7].

Проте основною позитивною зміною, яка суттєво змінила ситуацію щодо виконання місцевих бюджетів, стала реалізація реформи, спрямованої на проведення децентралізації місцевих бюджетів. Активна діяльність у проведенні реформи почалась у II половині 2014 року, і вже за наступний рік відбулась економічна стабілізація. Результати впливу цієї реформи на сумарні показники виконання місцевих бюджетів за доходами ілюструє рис. 2 [8].

Таке стрімке зростання наповнення місцевих бюджетів зумовлене успішним проведенням перших кроків у напрямі децентралізації та початку політичної стабілізації в країні. За період 2016 р. досліджуваний показник знизився на 123796,30 млн грн (коефіцієнт проросту склав $-42,04 \%$ ). Така зміна в обсягах виконання місцевих бюджетів за доходами зумовлена посиленням комплексного дестабілізуючого впливу внутрішніх і зовнішніх факторів. Протягом січня-грудня 2017 року надходження до загального фонду місцевих бюджетів України (без урахування міжбюджетних трансфертів) склали 192,0 млрд грн, 
що більше від прогнозних показників Мінфіну на 21,3 млрд грн, а, порівняно з 2016 роком, надходження зросли на 45,4 млрд грн або на $31 \%$.

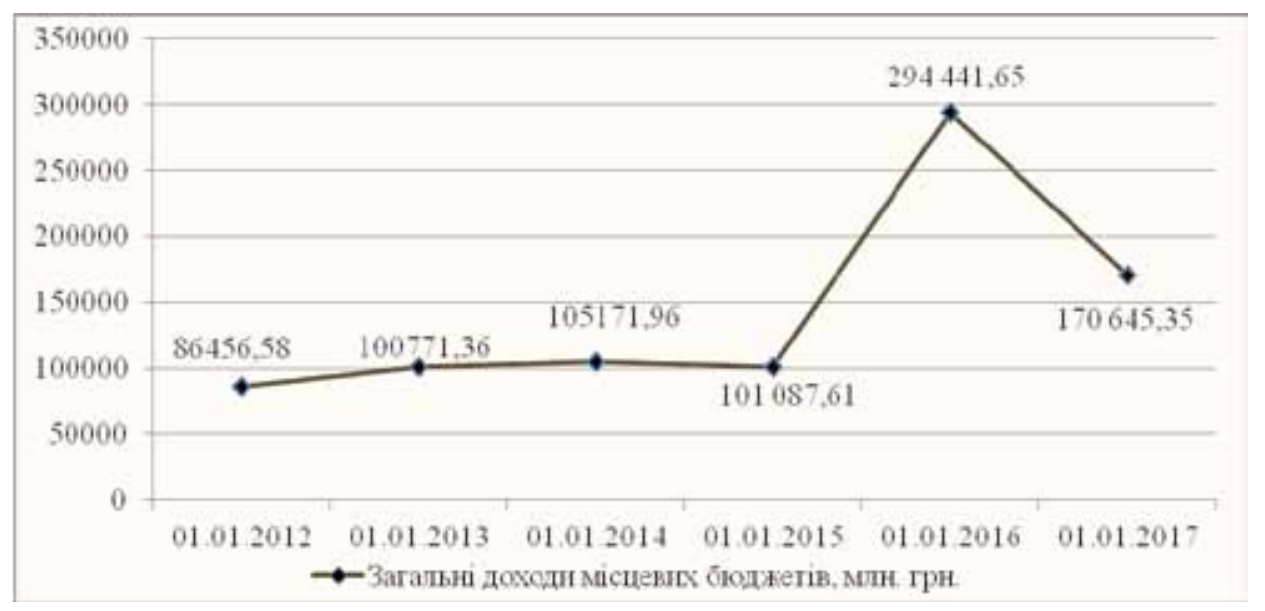

Рис. 2. Динаміка показника сумарного наповнення місцевих бюджетів України за період 2011-2016 рр., млн грн

Це свідчить про підвищення зацікавленості органів місцевого самоврядування у збільшенні надходжень до місцевих бюджетів, реалізації заходів щодо пошуку резервів їх наповнення та підвищення ефективності адміністрування податків і зборів. Частка фінансових ресурсів, які отримують місцеві бюджети 3 державного бюджету досягає 50\%, тобто органи місцевої влади володіють половиною фінансових ресурсів зведеного бюджету. Частка місцевих бюджетів у зведеному бюджеті досягає 50\%, тобто органи місцевої влади мають у своєму розпорядженні вагомий фінансовий ресурс, щоб ним ефективно управляти та спрямовувати на розвиток громад (у відносинах із державою - 50/50) [9].

Існування місцевих податків і зборів відповідає насамперед інтересам територіальних громад, від імені яких діють органи місцевого самоврядування, оскільки такі платежі є винятково їх фінансовою базою. Виходячи з цього, метою введення місцевих податків і зборів є забезпечення місцевих органів влади коштами, необхідними для здійснення їхніх завдань і функцій, що перебувають у їхньому самостійному розпорядженні і концентруються у відповідних бюджетах [10].

Рисунок 3 ілюструє, що за підсумками 2017 року частка місцевих податків і зборів у структурі власних доходів усіх місцевих бюджетів України склала 27,3\%, а бюджети об'єднаних територіальних громад коштом місцевих податків і зборів сформували майже $32 \%$ дохідної частини своїх бюджетів. Надалі очікують, що завдяки наявним інструментам і зацікавленості органів місцевого самоврядування в отриманні додаткових ресурсів частка місцевих податків і зборів буде зростати.

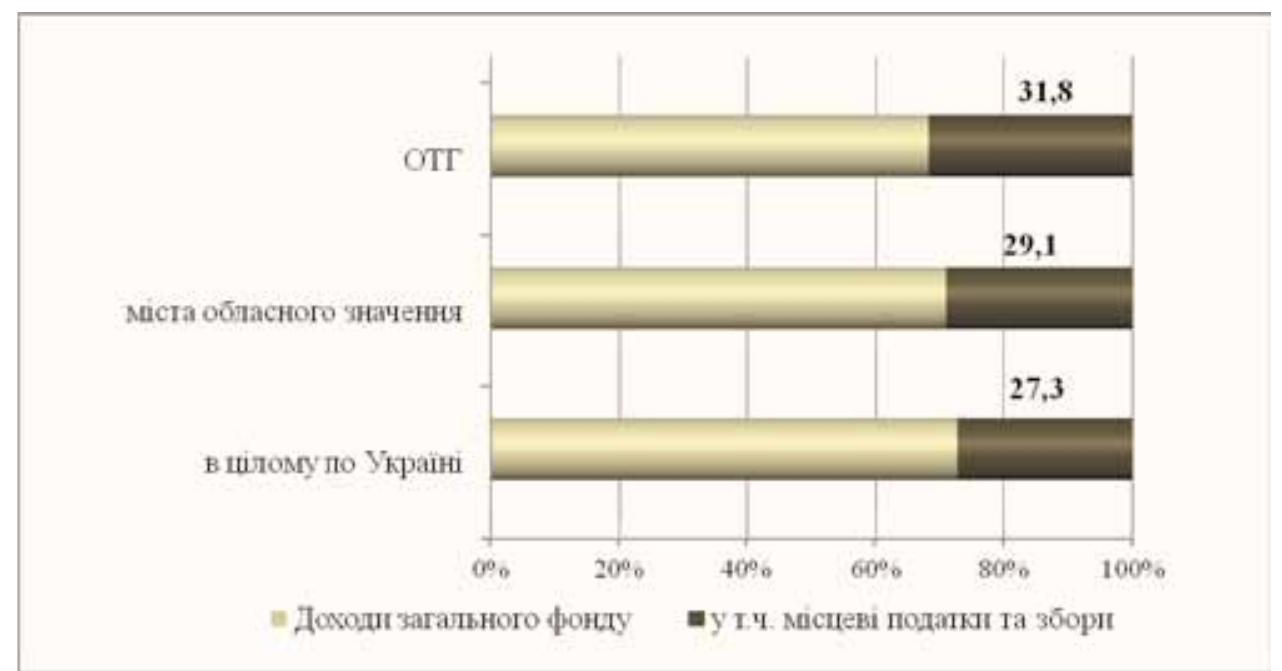

\section{Рис. 3. Частка місцевих податків та зборів у структурі місцевих бюджетів України за підсумками 2017 року, \%}

Щодо дослідження результатів фіскальної децентралізації та їх впливу на економічну діяльність адміністративно-територіальних одиниць, слід звернути увагу на кількість об'єктів, які фінансуються 3 
місцевих бюджетів. Так, приклад Дніпропетровської області свідчить, що за період проведення реформи, спрямованої на посилення фіскальної децентралізації регіонів, кількість проектів та об'єктів, які фінансуються з обласного бюджету, зросла майже в 9 разів. У 2015 році кількість зазначених об'єктів складала 67, а у 2017 році - 596, що дозволило розширити фінансові можливості області щодо підтримання належного стану об'єктів інфраструктури та стратегічного розвитку регіону [11]. На сьогодні фінансування 3 обласного бюджету охоплює всі сфери суспільного життя, які потребують утримання та фінансової підтримки. Передача фінансових ресурсів дозволяє органам місцевого самоврядування приймати оптимальні рішення щодо тих проектів, які потребують найбільшої уваги, та найбільш важливих стратегічних напрямів розвитку регіону.

Ключовою умовою процесу податкової та фіскальної децентралізації є не тільки формальне дотримання прав територіальних громад на місцеве самоврядування, але і забезпечення реальної спроможності вирішувати питання місцевого значення.

Звертаючи увагу на питання планування і наповнення місцевих бюджетів, необхідно відзначити, що на відміну від державного бюджету, під час реалізації бюджетного процесу на місцевому рівні окрім загальних засад програмно-цільового методу слід застосувати систему інтегративних підходів, яка дозволить підвищити ефективність роботи бюджетної системи в регіонах. Ця система містить основні підходи та заходи для успішного поглиблення реалізації фіскальної децентралізації, перелік яких ілюструє таблиця 1.

Аналіз таблиці дозволяє зробити висновок, що зазначена комплексна система підходів щодо підвищення ефективності децентралізаційних процесів в Україні тісно перетинається з моделлю соціальноекономічного розвитку, створюючи підгрунтя для iï реалізації в сучасних умовах.

Комплексна система підходів

Таблиия 1

\section{щодо підвищення ефективності децентралізаційних процесів в Україні}

\begin{tabular}{|c|c|}
\hline Підходи щодо реформування & Заходи для реалізації \\
\hline \multirow{3}{*}{$\begin{array}{l}\text { Удосконалення процесу адмі- } \\
\text { ністрування податку на доходи } \\
\text { фізичних осіб }\end{array}$} & Поступова заміна нормативів розмежування податку на доходи фізичних осіб. \\
\hline & $\begin{array}{l}\text { Розмежування ПДФО та передача надходжень за цим податком місцевим бюджетам } \\
\text { за місцем фактичного проживання (реєстрації) особи, доходи якої оподатковуються. }\end{array}$ \\
\hline & $\begin{array}{l}\text { Підвищення ефективності розподілу доходів від справляння ПДФО між адміні- } \\
\text { стративно-територіальними одиницями різних рівнів. }\end{array}$ \\
\hline \multirow{4}{*}{$\begin{array}{l}\text { Забезпечення повноцінного фор- } \\
\text { мування власних доходів місцевих } \\
\text { бюджетів }\end{array}$} & $\begin{array}{l}\text { Зміна нормативів щодо частки власних доходів місцевих бюджетів (тобто без } \\
\text { урахування трансфертів) у зведеному бюджеті. }\end{array}$ \\
\hline & Удосконалення системи адміністрування майнового податку. \\
\hline & Зміна бази оподаткування транспортного податку. \\
\hline & $\begin{array}{l}\text { Нормативне врегулювання додаткових надходжень до місцевих бюджетів за раху- } \\
\text { нок розширення власних джерел. }\end{array}$ \\
\hline \multirow{2}{*}{$\begin{array}{l}\text { Підвищення ефективності та про- } \\
\text { зорості використання бюджетних } \\
\text { коштів }\end{array}$} & $\begin{array}{l}\text { Упровадження на місцевих рівнях системи моніторингу виконання бюджетних } \\
\text { коштів. }\end{array}$ \\
\hline & Інформування громадськості за допомогою сучасних інформаційних технологій. \\
\hline \multirow{2}{*}{$\begin{array}{l}\text { Удосконалення механізму обслуго- } \\
\text { вування коштів місцевих бюджетів }\end{array}$} & $\begin{array}{l}\text { Перегляд норми щодо 5-денного терміну виконання платіжних доручень органів } \\
\text { місцевого самоврядування службою Держказначейства на предмет виключення } \\
\text { умови виконання доходів зведеного бюджету України. }\end{array}$ \\
\hline & $\begin{array}{l}\text { Посилення відповідальності за невчасне проведення платіжних доручень місцевих } \\
\text { бюджетів. }\end{array}$ \\
\hline \multirow{3}{*}{$\begin{array}{l}\text { Стимулювання органів місцевого } \\
\text { самоврядування до проведення } \\
\text { ефективної бюджетної політики, } \\
\text { що забезпечує рівний доступ гро- } \\
\text { мадян до суспільних послуг }\end{array}$} & $\begin{array}{l}\text { Удосконалення нормативно-правового регулювання системи міжбюджетних } \\
\text { трансфертів. }\end{array}$ \\
\hline & $\begin{array}{l}\text { Нормативно-правовий супровід оптимізації бюджетних установ в територіально- } \\
\text { адміністративних одиницях. }\end{array}$ \\
\hline & $\begin{array}{l}\text { Запровадження додаткових асигнувань або введення коригувальних коефіцієнтів } \\
\text { для фінансового забезпечення функції зберігання та реставрації будівель культур- } \\
\text { но-історичного значення. }\end{array}$ \\
\hline
\end{tabular}

Примітка. Систематизовано автором.

Висновки. Безперечно, посилення бюджетно-податкової децентралізації суттєво вплинуло на функціонування та умови розвитку місцевих бюджетів різних рівнів. Децентралізація доходів зазначених бюджетів дозволила створити умови для їх ефективного наповнення, а децентралізація видатків розширила можливості місцевого управління щодо фінансування об'єктів інфраструктури та стратегічного розвитку регіонів.

Фіскальна децентралізація в Україні як інструмент демократизації суспільства, підвищення ефективності адміністративної системи та якісного людського розвитку - процес об'єктивно виправданий і 
необхідний. Децентралізація необхідна для забезпечення ефективного надання послуг і максимального їхнього наближення до населення, вдосконалення системи управління та підвищення ефективності виконання завдань, що були передані на локальний рівень, на рівень територіальних об'єднань.

Водночас залишаються актуальними питання узгодження інтересів центральної влади й органів місцевого самоврядування в частині фіскальної політики, а також відповідальність органів місцевого самоврядування за обсяги надходжень і фінансування видатків на рівні територіальних утворень.

\section{Лiтература:} $967 \mathrm{c}$.

1. Мельничук О. С. Словник іншомовних слів. За ред. О.С. Мельничука. Київ: Головна редакція УРЕ, 1985.

2. Врублевський В. К. Політичний словник. За ред. В.К. Врублевського, А.В. Кудрицького, В.М. Мазура та ін. К.: 1982. 655 с.

3. Валігура В., Амбрик Л. Фінансові аспекти фіскальної децентралізації в Україні. Світ фінансів. 2016. № 2(47). C. $123-135$.

4. Бориславська О., Заверуха І., Захарченко Е. та ін. Децентралізація публічної влади: досвід європейських країн та перспективи України. Київ: Знання, 2012. 128 с.

5. Бюджетний кодекс України: документ № 2456-17 від 08.07.2010 p. // База даних «Законодавство України» / BP України. URL: http://zakon3.rada.gov.ua/laws/show/2456-17 (дата звернення: 10.05.2018).

6. Костенко О. А. Нові тенденції в розвитку міжбюджетних відносин в Україні. Науковий вісник Херсонського державного університету. 2016. № 21 (ч. 2). С. 157-160.

7. Про внесення змін до Бюджетного кодексу України (щодо реформи міжбюджетних відносин): Закон України № 1557 від 25.12.2014 р. // База даних «Законодавство України» / ВР України. URL: http://zakon2.rada. gov.ua/laws/show/79-19 (дата звернення: 10.05.2018).

8. Доходи місцевих бюджетів / Офіційний веб-сайт Державної Казначейської Служби України. 2018. 26 січня. URL: http://www.treasury.gov.ua/main/uk/publish/category/23596 (дата звернення: 10.05.2018).

9. Місцеві бюджети: експерти підбили перші підсумки 2017 року / Децентралізація дає можливості. 2018. 18 січня. URL: http://decentralization.gov.ua/news/8053?page=6 (дата звернення: 10.05.2018).

10. Хамініч С.Ю., Климова В. М. Особливості фіскальної децентралізації в умовах розвитку національного господарства України. Вісник Дніпропетровського університету (Серія «Економіка»). 2011. Вип. 5(2). C. $143-148$.

11. Відкритий бюджет Дніпропетровської облдержадміністрації. URL: http://www.openbudget.dp.gov.ua/ (дата звернення: 10.05.2018). 